\title{
Roles of PI3K/AKT/GSK3 Pathway Involved in Psychiatric Illnesses
}

\author{
Satoru Matsuda *(D), Yuka Ikeda, Mutsumi Murakami, Yukie Nakagawa, Ai Tsuji and \\ Yasuko Kitagishi \\ Department of Food Science and Nutrition, Nara Women's University, Kita-Uoya Nishimachi, Nara 630-8506, \\ Japan; tyvufkxaq1226-218@outlook.jp (Y.I.); murakamimc@gmail.com (M.M.); yukiie0028@yahoo.co.jp (Y.N.); \\ ai.tsuji0225@gmail.com (A.T.); y_kitagishi@live.jp (Y.K.) \\ * Correspondence: smatsuda@cc.nara-wu.ac; Tel./Fax: +81-742-20-3451
}

Received: 25 January 2019; Accepted: 11 February 2019; Published: 13 February 2019

check for updates

\begin{abstract}
Psychiatric illnesses may be qualified to the cellular impairments of the function for survival or death in neurons, which may consequently appear as abnormalities in the neuroplasticity. The molecular mechanism has not been well understood, however, it seems that PI3K, AKT, GSK3, and their downstream molecules have crucial roles in the pathogenesis. Through transducing cell surviving signal, the PI3K/AKT/GSK3 pathway may organize an intracellular central network for the action of the synaptic neuroplasticity. In addition, the pathways may also regulate cell proliferation, cell migration, and apoptosis. Several lines of evidence have supported a role for this signaling network underlying the development and treatment for psychiatric illnesses. Indeed, the discovery of molecular biochemical phenotypes would represent a breakthrough in the research for effective treatment. In this review, we summarize advances on the involvement of the PI3K/AKT/GSK3 pathways in cell signaling of neuronal cells. This study may provide novel insights on the mechanism of mental disorder involved in psychiatric illnesses and would open future opportunity for contributions suggesting new targets for diagnostic and/or therapeutic procedures.
\end{abstract}

Keywords: PI3K; AKT; GSK3; PTEN; cell signaling; schizophrenia; depression

\section{Introduction}

Psychiatric illnesses are conditions for which the precise underlying reason remains unknown; however, roles of dysregulation of the signaling related to neurotransmitters, intracellular signal transduction, and neural development have been emphasized in the pathogenesis of these illnesses [1]. For example, it has been shown that dysfunction of dopamine D1 and/or D5 receptor signaling is implicated in schizophrenia [2], which is linked to the activation of PI3K/AKT signaling with the subsequent inactivation of GSK3. Activation of AKT brings an increase in the phosphorylation of GSK3. In addition, the regulation of PI3K/AKT/GSK3 signaling has also been implicated in the etiology of mood disorders and depression [3]. In fact, molecular AKT deletion evokes a change in behavior reflecting the psychiatric appearance reminiscent of schizophrenia, anxiety and depression [4]. Several G protein-coupled receptors (GPCRs) and receptor tyrosine kinases (RTKs) are involved in the activation of the PI3K-/AKT-mediated signaling [5,6]. Consequently, it has been indicated that selective activation of these receptors may be efficacious in treating some neuropsychiatric disorders (Figure 1). Therefore, PI3K/AKT/GSK3 signaling might be critical underlying psychiatric-related behaviors. Therapeutic effects of various psychiatric drugs are also mediated in part by their inhibition of the signaling (Figure 1). For example, the mood stabilizer lithium has been used for the treatment of schizophrenia, depression, and other mental illnesses, which has been shown to inhibit the GSK3 signaling [7]. However, the molecular mechanism through which lithium regulates the 
signaling activities has been poorly understood. Identification of key signaling pathways should be critical to uncover novel therapeutic targets and successful clinical interventions. Moreover, a better understanding of the intricate PI3K/AKT/GSK3 actions may allow the rational development both for the diagnosis and treatments with enhanced efficacy.

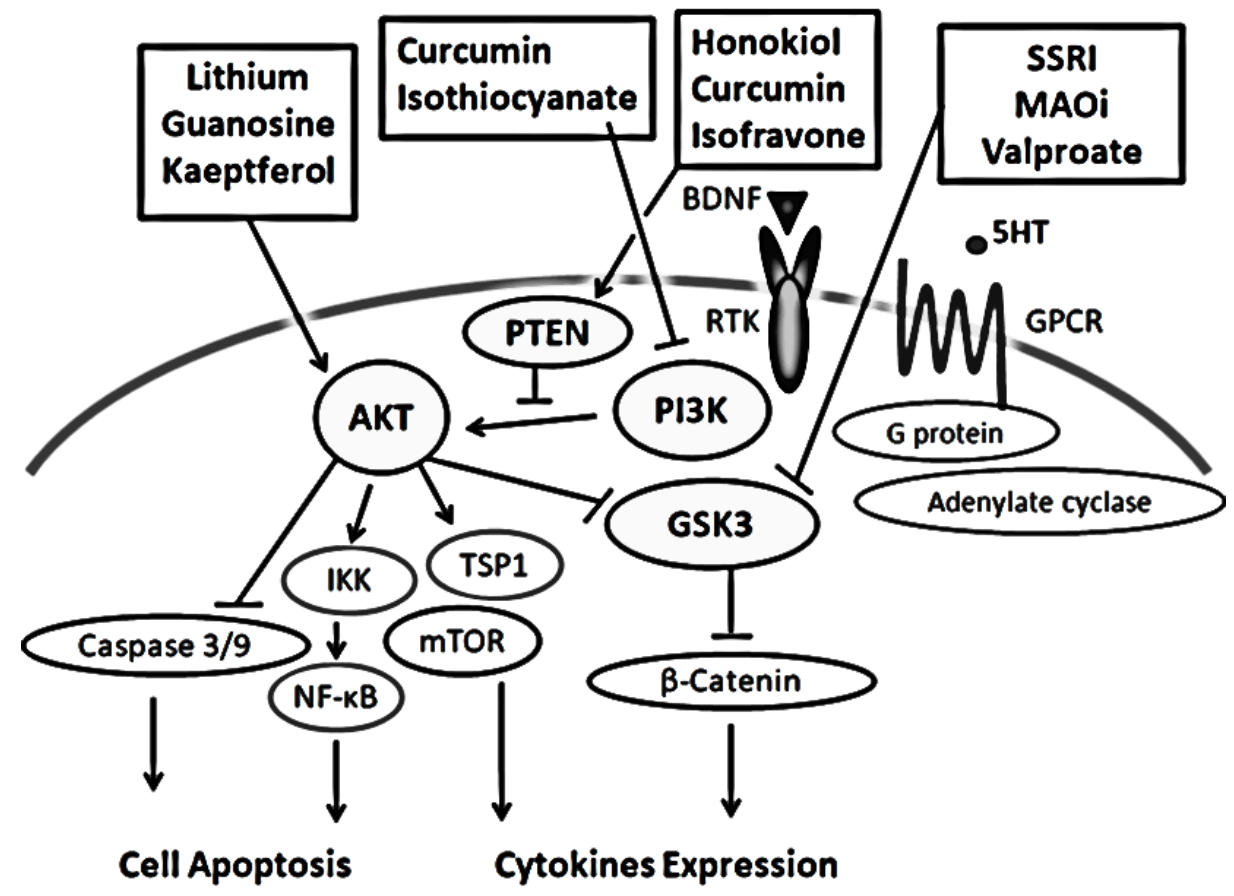

Figure 1. Potential antidepressants and several modulators linked to the predominant molecular targets on PI3K/AKT/GSK3 pathway are demonstrated. Arrowheads mean stimulation whereas hammerheads represent inhibition, suggesting implication of the PI3K/AKT/GSK3 modulators for the treatment of psychiatric illnesses. Note that some critical events have been omitted for clarity. SSRI: Selective Serotonin Reuptake Inhibitors, MAOi: Monoamine oxidase inhibitors, BDNF: Brain-derived neurotrophic factor, 5-HT: 5-hydroxytryptamine, serotonin.

\section{Characterization of the PI3K/AKT/GSK3 Signaling Pathway in the Pathogenesis of Psychiatric Illnesses}

Neuron survival mechanisms ordinarily depend on activation of phosphatidylinositol 3'-kinase (PI3K), which exists as a dimer comprising of a $110 \mathrm{kDa}$ catalytic subunit (p110) and an $85 \mathrm{kDa}$ (p85) regulatory subunit [8]. Downstream targets of cytoplasmic PI3K seem to affect cell apoptosis, cell metabolism, intracellular vesicles transport and so on [9]. The p110 subunit generates phosphoinositide PIP3 at the inner surface of plasma membrane, which supports to recruit the phosphoinositide dependent protein kinase-1 (PDK1) via its pleckstrin homology domain (PH). PDK1 phosphorylates then activate the AKT serine/threonine kinase. The production of PIP3s by PI3K at the plasma membrane is essential for the recruitment and activation of $\mathrm{PH}$ domain-containing proteins. This PI3K-PDK1-AKT signaling pathway is required for the survival of several neuronal cells [10]. The AKT kinase family is constituted by three isoforms termed AKT1, AKT2, and AKT3, which is implicated in a variety of cellular processes such as cell growth and survival. Although they are showing robust homologies, each isoform is encoded by a distinct gene [11]. The most abundant one is AKT1, which is ubiquitously expressed. AKT2 is expressed in insulin-responsive tissues including muscle, and AKT3 is considerably expressed in brain and testis [12]. Some lethality is observed in AKT1 KO mice and the surviving mice are extensively reduced in size [13]. AKT1 is phosphorylated by the PDK1 and by PDK2 [14]. AKT2 is important for glucose metabolism. In addition, signs of anxiety and depressive-like behaviors have been reported in AKT2 KO mice [15]. AKT3 KO mice 
exhibit small brains [16], suggesting that AKT3 could be an important regulator of brain development. In addition, AKT3 might also play a pivotal role in human brain pathologies such as schizophrenia. It is remarkable that studies have identified AKT3 as a potential contributor to schizophrenia $[17,18]$. Actually, deletion of AKT3 increases susceptibility to develop symptoms related to the disease [18]. Therefore, all AKT signaling may contribute to the functioning of neural networks prevailing in the symptoms associated with psychiatric diseases. AKT localize mostly to the cytoplasm, but they can also translocate in the nucleus on an extracellular stimulation. Nuclear PIP3s may mediate a broad range of processes including DNA damage response and cell cycle regulation [19,20].

The tumor suppressor PTEN, phosphatase and tensin homolog on chromosome 10, is a dual-specificity phosphatase with protein phosphatase activity and lipid phosphatase activity. Cells that lack PTEN have constitutively high levels of PIP3 and could activate downstream PI3K/AKT [21]. Conversely, overexpression of PTEN might be related to the activation of the cell apoptosis which can be correlated with repression of PI3K/AKT signaling [21]. Accordingly, neuronal cell survival and/or cell death may be attributed in part to the variations in PTEN expression [21]. Inhibition of PTEN saves normal synaptic function and thereby cognition in animal models of Alzheimer's disease [22]. Conversely, overexpression of PTEN exhibits synaptic depression that imitates psychological depression [23]. PTEN mutations have been described in several patients with autism spectrum disorders (ASDs) and macrocephaly [24]. AKT activation by downregulation of PTEN might be significant to keep its neuro-protective effects.

The GSK3 family is composed of two isoenzymes termed GSK3 $\alpha$ and GSK3 $\beta$, which have been initially recognized for the roles in insulin receptor signaling. GSK3 is constitutively active serine/threonine kinase in cells. The activity of GSK3 is positively regulated by phosphorylation on tyrosine residues (Thy 279 for GSK3 $\alpha$ and Thy 216 for GSK3 $\beta$ ) [25] and negatively regulated by serine phosphorylation (Ser 21 for GSK3 $\alpha$ and Ser 9 for GSK3 $\beta$ ) [26]. A known negative regulator of GSK3 is a member of AKT. Phosphorylation of AKT on Thr 308 has been shown to be essential and sufficient for the regulation of GSK3 by AKT [14]. Levels of phosphorylated GSK3 are strongly decreased in the hippocampus of AKT3 KO mice. Circadian rhythm in phosphorylation of GSK3 $\beta$, but not GSK3 $\alpha$, in hippocampal neurons has been reported [27]. Overall, the effect of depletion in brain GSK3 activity is a reduction in anxiety level that is associated with an increase in the beginning of social interaction.

\section{Some Diagnostic Clues for Psychiatric Illnesses at the Molecules Involved in PI3K/AKT/GSK3 Pathway}

In general, high mortality of diseases is mostly due to a lack of effective treatments and efficient markers for early diagnosis. The PI3K/AKT/GSK3 signaling cascade may be a center for psychiatric illnesses. If alteration of the signaling activities in brain neurons should be also detected in peripheral blood lymphocytes of illnesses patients, it could work for efficient diagnosis of the illnesses. In human lymphocytes, levels of PI3K subunit p110 have been impaired in patients with schizophrenia [28]. On the other hand, SNP within the PI3K subunit p85-gene is associated with a risk of alcohol drinking behavior [29]. It is remarkable that AKT1 has been originally identified as a possible susceptibility gene for schizophrenia [30]. AKT2 deletion has also been associated with anxiety- and depression-like behaviors [15,31]. In addition, injured AKT3 genes have been associated with psychiatric illnesses including schizophrenia. In consistent with this, AKT3 KO mice have demonstrated a phenotype reminiscent of depression and schizophrenia. In addition, characters of animals with the AKT3 deletion have shown microcephaly [32], whereas high-AKT3 activities are associated with macrencephaly [33]. Psychiatric behaviors might be induced from the reduced brain volume brought by reduced AKT activity. Remarkably, alteration of the GSK3 activity has also been recognized as a schizophrenia risk factor [34]. Tissue samples from post mortem patients with schizophrenia have exhibited considerable reductions of the phosphorylated AKT levels in neurons [35]. Furthermore, AKT activity has also been reduced in some brain regions of major depression patients [36]. Phosphorylated AKT levels have been shown as decreased in a depression animal model [37]. Activation of the 
dopamine receptor 2 (D2R) has been revealed to stimulate the inactivation of the AKT by the protein phosphatase 2A [38], suggesting that GPCR activation could regulate the AKT in response to extracellular signals. An endogenous neuro-steroid in the central nervous system, pregnenolone, normalizes schizophrenia-like behaviors via the AKT signaling [39]. Thus, PI3K/AKT/GSK3 signaling may play a critical role in psychiatric appearances.

GSK3 knock-in mice have revealed high susceptibility to depressive behaviors [40]. In addition, impaired GSK3 activity has been documented to play a role in psychiatric conditions [41]. High activity of GSK3 has been found in bipolar disorder with circadian dysregulation [42]. Some anxiety and depressive behaviors have been revealed to be associated with lower brain levels of the phosphorylated GSK3 [43]. In particular, GSK3 $\beta$ is a common target of several psychoactive drugs. On the other hand, mutations in the PTEN are also extremely related with autism and macrocephaly. In addition, loss of PTEN may lead to an overall loss in interneurons [44]. Some mutations of the PTEN gene may disrupt the normally balanced nuclear-cytoplasmic localization of the PTEN phosphatase, which causes inappropriate behavior, a profile reminiscent of ASD, in animal models [45].

Noncoding 20-25-nucleotide-long RNAs termed microRNAs (miRNAs) have biological functions such as cellular proliferation and apoptosis, which could modulate gene expression by miRNA-induced silencing. The potential application of miRNAs has been considered as an early detection biomarker for illnesses. Genome studies have revealed genetic variants adjoining a miR-137 region may contribute to schizophrenia risk [46], suggesting that dysregulation of the miR-137 may contribute to schizophrenia pathogenesis by modifying neurodevelopmental signaling [47]. AKT signaling pathway has been shown involved in the miR-137 pathway [48]. In addition, miR-144-3p seems to be a viable target for posttraumatic stress disorder and related disorders [49]. Furthermore, several miRNAs including miR-16, miR-182, miR-223, and miR-451 have shown potential biomarkers in the condition of depression [50,51]. The miRNA-mediated modification of gene expression has been in part revealed via the PI3K/AKT/GSK3 signaling [51]. In relation to those, miRNAs let-7b and let-7c are also potential biomarkers of treatment-resistant depression, which regulates the expression of several genes in the PI3K/AKT/GSK3 pathway [52].

\section{Some Diets With Phytocompounds May Contribute to the Neuro-protection in the Psychiatric Diseases via the Modulation of PI3K/AKT/GSK3 Signaling}

Mood stabilizers, antidepressants and antipsychotics all may upturn the PI3K/AKT/GSK3 signaling [53], resulting in the regulation of GSK3 [53]. For example, schisandrin has an antidepressant-like effect, which possibly mediated partly by adjusting the PI3K/AKT/GSK3 signaling [54]. Furthermore, lithium administration repairs the phosphorylated GSK3 levels and improves anxiety-related behavior, which regulates neuronal cell death and increases neurogenesis. So, antidepressants such as lithium may protect the functional neuroplasticity in neurons associated with the depression. Lithium is an inhibitor of magnesium and can competitively inhibit Mg2+-ATP-dependent catalytic activity of the GSK3. The antipsychotic drug haloperidol has been linked to the inhibition of the AKT signaling [55]. In consistent with this, methamphetamine could induce psychosis, which is associated with highly increased expression of AKT [56].

As the efficacy of pharmacological treatments has been imperfect and had unexpected side effects, psychiatric illnesses represent a significant public health problem. A number of preventive factors have been suggested by epidemiological research including lifestyle factors such as diet and physical exercise. Among them, dietary choices could play certain roles in the neuroprotection. In addition, some involvements of food ingredients might be promising in the prevention of brain dysfunction by modifying the PI3K/AKT/GSK3 signaling. For example, an active ingredient derived from the root of Curcuma longa used as culinary turmeric, curcumin, can improve synaptic plasticity and enhance memory abilities [57]. The neuroprotection of the curcumin might be mediated through the modification of PI3K/AKT/GSK3 signaling [58]. In addition, the curcumin prevents oxidative stress via the regulation of the PI3K/AKT/GSK3 signaling [59]. Several plants or fruits may also be 
encouraging. A flavanone found in a variety of plants, Liquiritigenin, might be useful for the treatment of major depression via the modification of PI3K/AKT/GSK3 signaling [60]. Kaempferol is also a flavonol existing in several plants with grapefruit and some edible berries, which could protect some neurons [61]. On the contrary, exposure to high fat interrupts brain dopamine networks through the declines of striatal AKT activity [62]. Serine phosphorylation of GSK3 has been reduced in experimental animal models fed with a diet containing abundant stearic and/or palmitic acid [63]. Fatty acids such as DHA and EPA, omega-3 fatty acids found in fish, may also modulate neurotransmitters and support neurogenesis [64]. Supplementation with the omega-3 fatty acids has improved symptoms of depression patients [65]. In addition, consumption of the omega-3 fatty acids has mood-stimulating effects in patients [66]. Fatty acids supplementation has also shown positive effects in schizophrenia [67]. Anti-depressant effects of the omega-3 fatty acids could be induced by upregulation of the PI3K/AKT/GSK3 pathway [68].

Neuroprotection by inhibiting PTEN tumor suppressor with food ingredients has been described by activating the PI3K/AKT/GSK3 signaling in neuronal cells. For example, a traditional medicinal herb ingredient, Icariin, inhibits the PTEN expression following the AKT activation [69]. In addition, an active component isolated from Chinese traditional herb magnolia, Honokiol, may be able to attenuate PI3K/AKT/GSK3 signaling by upregulation of the PTEN expression [70]. Generally, dietary exposure to phytoestrogens including soy isoflavones may result in an increase of PTEN expression. Genistein and/or quercetin have an outcome to upregulate PTEN transcription following suppression of the PI3K/AKT/GSK3 pathway. Dietary intake of a phytochemical found in some vegetables such as indole-3-carbinol also upregulates PTEN expression [71]. As the PTEN expression is induced by the activated PPARs, this may also suggest a potential therapeutic quality for the management of PI3K/AKT/GSK3-related diseases. A wide variety of compounds have been identified as PPAR ligands including omega-3 fatty acids [72], which have a valuable effect on the risk factors for metabolic diseases. Linoleic acid could also bind PPAR $\delta$ very well [73]. Fish oil diets have significantly increased the level of PTEN expression to reduce PI3K/AKT/GSK3 signaling [74]. These might be distinguished as a rational basis for the development of dietary treatments for psychiatric illnesses.

\section{So What Next in Perspectives?}

Lifestyle interventions such as dietary education could be promising and cost-effective for people with psychiatric illnesses. However, despite those experimental observations, the precise mechanisms for food ingredients remain elusive for clinical uses. A number of studies have examined the association between diet and behavioral states, but the findings have been inadequate. In addition, the relation between nutrient intake and neuroprotection activity is intricate. Whereas many questions remain to be answered about the roles of PI3K/AKT/GSK3 signaling in psychiatric disorders, it is possible that the PI3K/AKT/GSK3 signaling of neuronal populations in a certain brain area could be associated with distinct behavioral outcomes. It seems that both activation and inhibition of those molecules, if they drive one-sidedly, may not contribute to the improvement of the neuronal disorders (Figure 2). It seems that back-and-forth activation and/or inhibition for the appropriate balance may be very important (Figure 3). In other words, the functional balance of the activity of kinases may be essential. Strategies for seeking efficient therapy to determine whether it is related to the improved brain function and the preservation of brain health should develop the observation in key pathways required for brain homeostasis. Several nutriment and/or dietary components may contribute to the balance via the modulation of the kinase activities (Figure 3). Future findings might be translated into new dietary managements for the treatment of the disorders. Indeed, the PI3K/AKT/GSK3 pathway seems to be critical for the maintenance in brain neurons. Additionally, it seems important to exploit the potential benefits of optimal treatment and/or combination with PI3K/AKT chemical modulators. More understanding of the precise intracellular mechanisms downstream of PI3K/AKT/GSK3 changes in psychiatric illnesses could provide novel insights into the development of new therapeutic approaches with greater efficacy. 

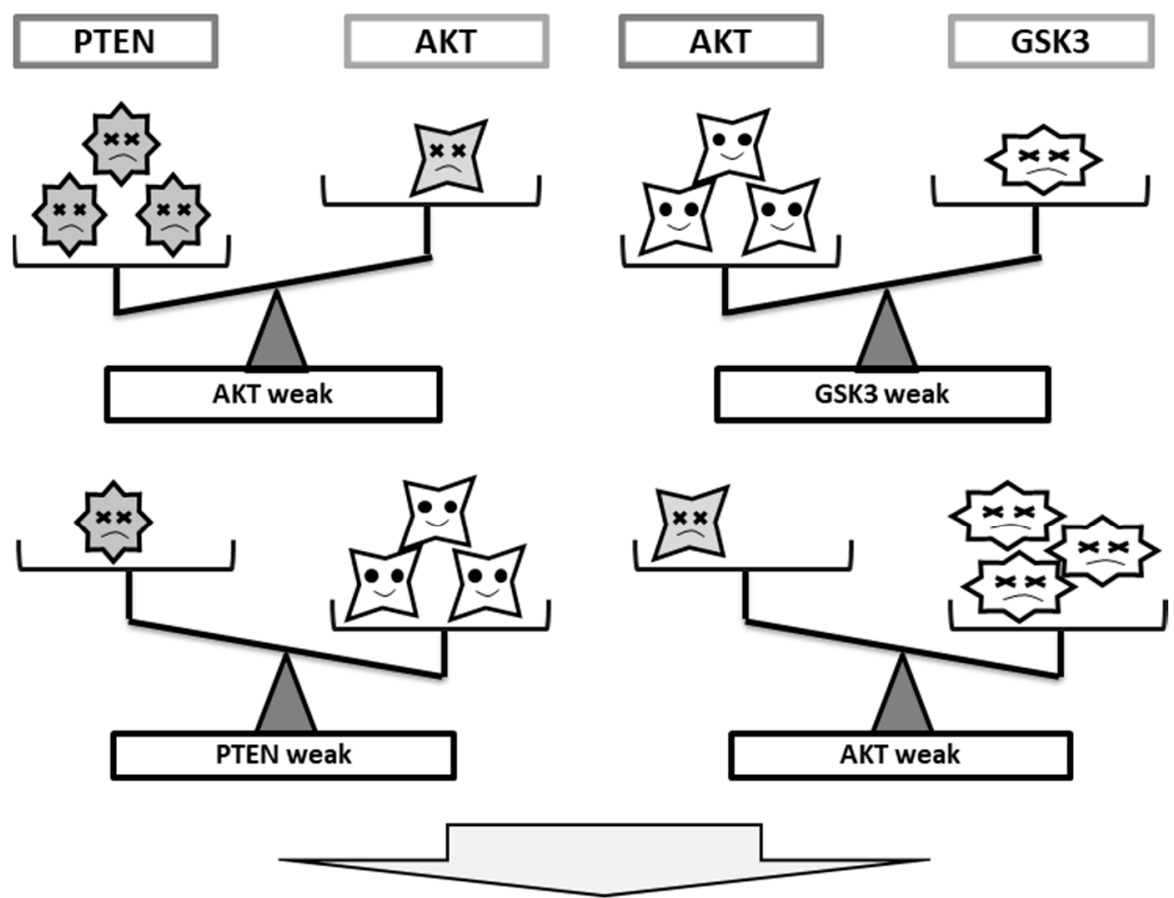

\section{Psychiatric Disorders}

Figure 2. Imbalance of the activity among PTEN, AKT, and GSK3 may contribute to the pathogenesis of psychiatric disorders.
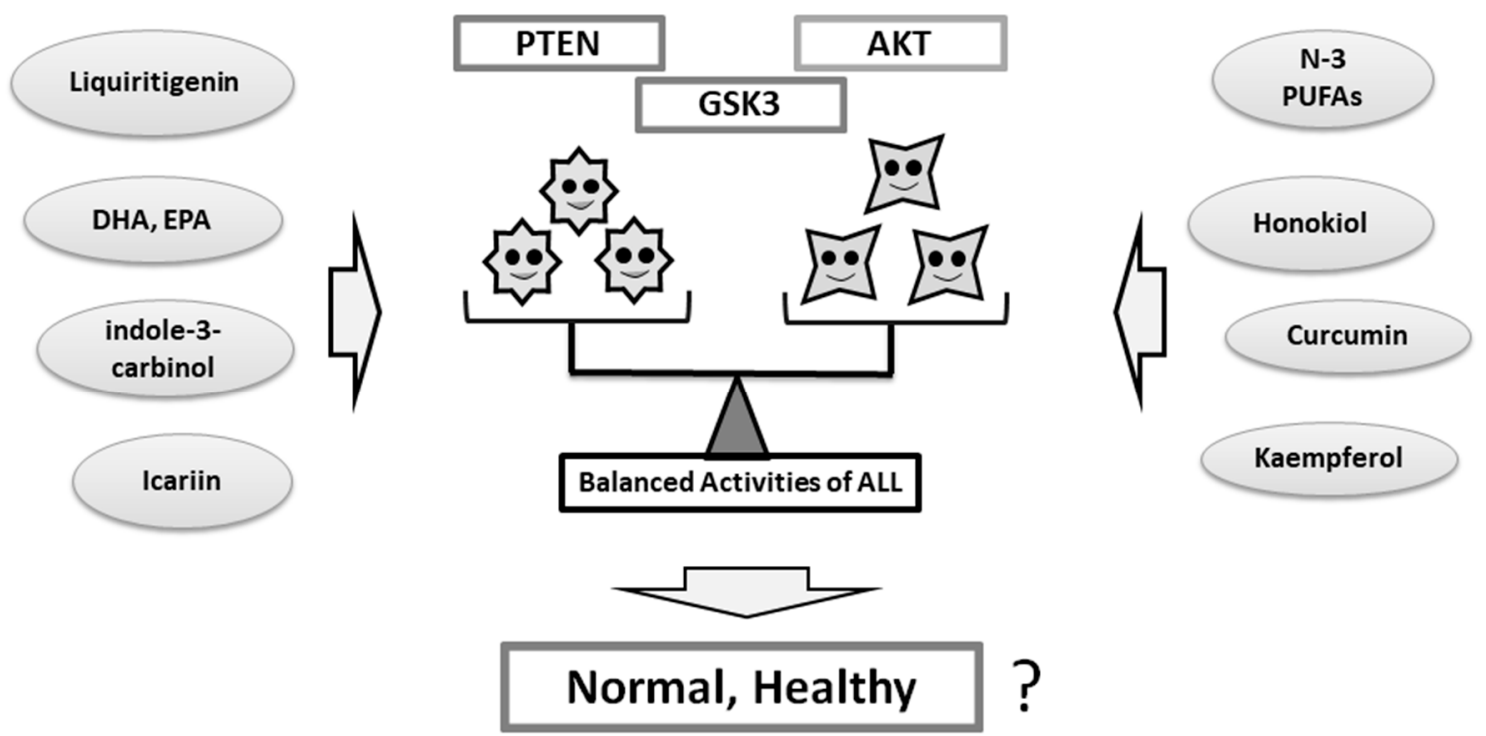

Figure 3. The balance of PTEN, AKT, and GSK3 in the meaning of their functions may be important for individual psychiatric health. Several food and/or dietary components may provide improved balance of the signaling via the modulation of the functional activities.

\section{Conclusions}

In conclusion, progress in understanding molecular key targets in order to develop new therapeutics for psychiatric illnesses would undoubtedly benefit this research field. The involvement of PI3K/AKT/GSK3 signaling in schizophrenia and mood disorders is highly relevant. Some diets may contribute to the neuro-protection in psychiatric illnesses via the modulation of the intracellular 
neuronal signaling. Therefore, improving treatments for human neuropsychiatric disorders by dietary approach is particularly challenging. Further investigation on the neuronal signaling could lead to a better understanding of the molecular basis implicated in neuropsychiatric illnesses.

Author Contributions: Each author participated sufficiently in the work of drafting the article and/or revising the article for the rational content. Then, authors gave approval of the final version.

Funding: This research received no external funding.

Acknowledgments: This work was supported in part by JSPS KAKENHI Grant Number JP18K17964. In addition, this work was supported in part by the grant from Nara Women's University in Japan.

Conflicts of Interest: The authors declare that they have no competing financial interests.

$\begin{array}{ll}\text { Abbreviations } \\ \text { ASD } & \text { Autism Spectrum Disorder } \\ \text { DHA } & \text { docosahexaenonic acids } \\ \text { EPA } & \text { eicosopentaenoic acid } \\ \text { GSK3 } & \text { Glycogen synthase kinase } 3 \\ \text { 5-HT } & \text { 5-hydroxytryptamine, serotonin } \\ \text { mTOR } & \text { mammalian target of rapamycin } \\ \text { PIP3 } & \text { phosphatidylinositol 3,4,5-triphosphate } \\ \text { PI3K } & \text { phosphatidylinositol-3 kinase } \\ \text { PPAR } \gamma & \text { Peroxisome Proliferator-Activated Receptor } \gamma \\ \text { PTEN } & \text { Phosphatase and tensin homolog on chromosome } 10 \\ \text { ROS } & \text { reactive oxygen species } \\ \text { SSRIs } & \text { selective serotonin reuptake inhibitors }\end{array}$

\section{References}

1. Vriend, C. The neurobiology of impulse control disorders in Parkinson's disease: From neurotransmitters to neural networks. Cell Tissue Res. 2018, 373, 327-336. [CrossRef] [PubMed]

2. Goldman-Rakic, P.S.; Castner, S.A.; Svensson, T.H.; Siever, L.J.; Williams, G.V. Targeting the dopamine D1 receptor in schizophrenia: Insights for cognitive dysfunction. Psychopharmacology 2004, 174, 3-16. [CrossRef] [PubMed]

3. Beaulieu, J.M. A role for Akt and glycogen synthase kinase-3 as integrators of dopamine and serotonin neurotransmission in mental health. J. Psychiatry Neurosci. 2012, 37, 7-16. [CrossRef] [PubMed]

4. Nestler, E.J.; Hyman, S.E. Animal models of neuropsychiatric disorders. Nat. Neurosci. 2010, 13, 1161-1169. [CrossRef] [PubMed]

5. Lemmon, M.A.; Schlessinger, J. Cell signaling by receptor tyrosine kinases. Cell 2010, 141, 1117-1134. [CrossRef]

6. Swift, J.L.; Godin, A.G.; Doré, K.; Freland, L.; Bouchard, N.; Nimmo, C.; Sergeev, M.; De Koninck, Y.; Wiseman, P.W.; Beaulieu, J.M. Quantification of receptor tyrosine kinase transactivation through direct dimerization and surface density measurements in single cells. Proc. Natl. Acad. Sci. USA 2011, 108, 7016-7021. [CrossRef]

7. Freland, L.; Beaulieu, J.M. Inhibition of GSK3 by lithium, from single molecules to signaling networks. Front. Mol. Neurosci. 2012, 5, 14. [CrossRef]

8. Kang, H.; Schneider, H.; Rudd, C.E. Phosphatidylinositol 3-kinase p85 adaptor function in T-cells. Co-stimulation and regulation of cytokine transcription independent of associated p110. J. Biol. Chem. 2002, 277, 912-921. [CrossRef]

9. He, W.; Yuan, Q.H.; Zhou, Q. Histamine H3 receptor antagonist Clobenpropit protects propofol-induced apoptosis of hippocampal neurons through PI3K/AKT pathway. Eur. Rev. Med. Pharmacol. Sci. 2018, $22,8013-8020$.

10. Zhou, X.; Cordon-Barris, L.; Zurashvili, T.; Bayascas, J.R. Fine-tuning the intensity of the PKB/Akt signal enables diverse physiological responses. Cell Cycle 2014, 13, 3164-3168. [CrossRef] 
11. Diez, H.; Garrido, J.J.; Wandosell, F. Specific roles of Akt iso forms in apoptosis and axon growth regulation in neurons. PLoS ONE 2012, 7, e32715. [CrossRef] [PubMed]

12. Hers, I.; Vincent, E.E.; Tavaré, J.M. Akt signalling in health and disease. Cell. Signal. 2011, 23, $1515-1527$. [CrossRef] [PubMed]

13. Yang, Z.Z.; Tschopp, O.; Hemmings-Mieszczak, M.; Feng, J.; Brodbeck, D.; Perentes, E.; Hemmings, B.A. Protein kinase B alpha/Akt1 regulates placental development and fetal growth. J. Biol. Chem. 2003, 278, 32124-32131. [CrossRef]

14. Jacinto, E.; Facchinetti, V.; Liu, D.; Soto, N.; Wei, S.; Jung, S.Y.; Huang, Q.; Qin, J.; Su, B. SIN1/MIP1 maintains rictor-mTOR complex integrity and regulates Akt phosphorylation and substrate specificity. Cell 2006, 127, 125-137. [CrossRef] [PubMed]

15. Leibrock, C.; Ackermann, T.F.; Hierlmeier, M.; Lang, F.; Borgwardt, S.; Lang, U.E. Akt2 deficiency is associated with anxiety and depressive behavior in mice. Cell. Physiol. Biochem. 2013, 32, 766-777. [CrossRef] [PubMed]

16. Poduri, A.; Evrony, G.D.; Cai, X.; Elhosary, P.C.; Beroukhim, R.; Lehtinen, M.K.; Hills, L.B.; Heinzen, E.L.; Hill, A.; Hill, R.S.; et al. Somatic activation of AKT3 causes hemispheric developmental brain malformations. Neuron 2012, 74, 41-48. [CrossRef] [PubMed]

17. Bergeron, Y.; Bureau, G.; Laurier-Laurin, M.É.; Asselin, E.; Massicotte, G.; Cyr, M. Genetic Deletion of Akt3 Induces an Endophenotype Reminiscent of Psychiatric Manifestations in Mice. Front. Mol. Neurosci. 2017, 10, 102. [CrossRef] [PubMed]

18. Howell, K.R.; Floyd, K.; Law, A.J. PKB $\gamma /$ AKT3 loss-of-function causes learning and memory deficits and deregulation of AKT/mTORC2 signaling: Relevance for schizophrenia. PLoS ONE 2017, 12, e0175993. [CrossRef] [PubMed]

19. Choi, B.H.; Chen, Y.; Dai, W. Chromatin PTEN is involved in DNA damage response partly through regulating Rad52 sumoylation. Cell Cycle 2013, 12, 3442-3447. [CrossRef] [PubMed]

20. Bassi, C.; Ho, J.; Srikumar, T.; Dowling, R.J.; Gorrini, C.; Miller, S.J.; Mak, T.W.; Neel, B.G.; Raught, B.; Stambolic, V. Nuclear PTEN controls DNA repair and sensitivity to genotoxic stress. Science 2013, 341, 395-399. [CrossRef]

21. Matsuda, S.; Nakagawa, Y.; Tsuji, A.; Kitagishi, Y.; Nakanishi, A.; Murai, T. Implications of PI3K/AKT/PTEN Signaling on Superoxide Dismutases Expression and in the Pathogenesis of Alzheimer's Disease. Diseases 2018, 6, E28. [CrossRef] [PubMed]

22. Cui, W.; Wang, S.; Wang, Z.; Wang, Z.; Sun, C.; Zhang, Y. Inhibition of PTEN Attenuates Endoplasmic Reticulum Stress and Apoptosis via Activation of PI3K/AKT Pathway in Alzheimer's Disease. Neurochem. Res. 2017, 42, 3052-3060. [CrossRef] [PubMed]

23. Knafo, S.; Esteban, J.A. PTEN: Local and Global Modulation of Neuronal Function in Health and Disease. Trends Neurosci. 2017, 40, 83-91. [CrossRef]

24. Hobert, J.A.; Embacher, R.; Mester, J.L.; Frazier, T.W.; Eng, C. Biochemical screening and PTEN mutation analysis in individuals with autism spectrum disorders and macrocephaly. Eur. J. Hum. Genet. 2014, 22, 273-276. [CrossRef] [PubMed]

25. Lochhead, P.A.; Kinstrie, R.; Sibbet, G.; Rawjee, T.; Morrice, N.; Cleghon, V. A chaperone-dependent GSK3beta transitional intermediate mediates activation-loop autophosphorylation. Mol. Cell 2006, 24, 627-633. [CrossRef] [PubMed]

26. Sutherland, C.; Cohen, P. The alpha-isoform of glycogen synthase kinase-3 from rabbit skeletal muscle is inactivated by p70 S6 kinase or MAP kinase-activated protein kinase-1 in vitro. FEBS Lett. 1994, 338, 37-42. [CrossRef]

27. Besing, R.C.; Rogers, C.O.; Paul, J.R.; Hablitz, L.M.; Johnson, R.L.; McMahon, L.L.; Gamble, K.L. GSK3 activity regulates rhythms in hippocampal clock gene expression and synaptic plasticity. Hippocampus 2017, 27, 890-898. [CrossRef]

28. Law, A.J.; Wang, Y.; Sei, Y.; O’Donnell, P.; Piantadosi, P.; Papaleo, F.; Straub, R.E.; Huang, W.; Thomas, C.J.; Vakkalanka, R.; et al. Neuregulin 1-ErbB4-PI3K signaling in schizophrenia and phosphoinositide 3-kinase-p1108 inhibition as a potential therapeutic strategy. Proc. Natl. Acad. Sci. USA 2012, 109, 12165-12170. [CrossRef]

29. Desrivières, S.; Krause, K.; Dyer, A.; Frank, J.; Blomeyer, D.; Lathrop, M.; Mann, K.; Banaschewski, T.; Laucht, M.; Schumann, G. Nucleotide sequence variation within the PI3K p85 alpha gene associates with alcohol risk drinking behaviour in adolescents. PLoS ONE 2008, 3, e1769. [CrossRef] 
30. Emamian, E.S.; Hall, D.; Birnbaum, M.J.; Karayiorgou, M.; Gogos, J.A. Convergent evidence for impaired AKT1-GSK3beta signaling in schizophrenia. Nat. Genet. 2004, 36, 131-137. [CrossRef]

31. Li, G.; Anderson, R.E.; Tomita, H.; Adler, R.; Liu, X.; Zack, D.J.; Rajala, R.V. Nonredundant role of Akt2 for neuroprotection of rod photoreceptor cells from light-induced cell death. J. Neurosci. 2007, 27, $203-211$. [CrossRef] [PubMed]

32. Boland, E.; Clayton-Smith, J.; Woo, V.G.; McKee, S.; Manson, F.D.; Medne, L.; Zackai, E.; Swanson, E.A.; Fitzpatrick, D.; Millen, K.J.; et al. Mapping of deletion and translocation breakpoints in 1q44 implicates the serine/threonine kinase AKT3 in postnatal microcephaly and agenesis of the corpus callosum. Am. J. Hum. Genet. 2007, 81, 292-303. [CrossRef] [PubMed]

33. Rivière, J.B.; Mirzaa, G.M.; O’Roak, B.J.; Beddaoui, M.; Alcantara, D.; Conway, R.L.; St-Onge, J. De novo germline and postzygotic mutations in AKT3, PIK3R2 and PIK3CA cause a spectrum of related megalencephaly syndromes. Nat. Genet. 2012, 44, 934-940. [CrossRef] [PubMed]

34. Yan, P.; Qiao, X.; Wu, H.; Yin, F.; Zhang, J.; Ji, Y.; Wei, S.; Lai, J. An Association Study Between Genetic Polymorphisms in Functional Regions of Five Genes and the Risk of Schizophrenia. J. Mol. Neurosci. 2016, 59, 366-375. [CrossRef] [PubMed]

35. Balu, D.T.; Carlson, G.C.; Talbot, K.; Kazi, H.; Hill-Smith, T.E.; Easton, R.M.; Birnbaum, M.J.; Lucki, I. Akt1 deficiency in schizophrenia and impairment of hippocampal plasticity and function. Hippocampus 2012, 22, 230-240. [CrossRef] [PubMed]

36. Karege, F.; Perroud, N.; Burkhardt, S.; Schwald, M.; Ballmann, E.; La Harpe, R.; Malafosse, A. Alteration in kinase activity but not in protein levels of protein kinase $B$ and glycogen synthase kinase-3beta in ventral prefrontal cortex of depressed suicide victims. Biol. Psychiatry 2007, 61, 240-245. [CrossRef] [PubMed]

37. Krishnan, V.; Han, M.H.; Mazei-Robison, M.; Iñiguez, S.D.; Ables, J.L.; Vialou, V.; Berton, O.; Ghose, S.; Covington, H.E.; Wiley, M.D.; et al. AKT signaling within the ventral tegmental area regulates cellular and behavioral responses to stressful stimuli. Biol. Psychiatry 2008, 64, 691-700. [CrossRef] [PubMed]

38. Beaulieu, J.M.; Sotnikova, T.D.; Marion, S.; Lefkowitz, R.J.; Gainetdinov, R.R.; Caron, M.G. An Akt/beta-arrestin 2/PP2A signaling complex mediates dopaminergic neurotransmission and behavior. Cell 2005, 122, 261-273. [CrossRef] [PubMed]

39. Wong, P.; Sze, Y.; Chang, C.C.; Lee, J.; Zhang, X. Pregnenolone sulfate normalizes schizophrenia-like behaviors in dopamine transporter knockout mice through the AKT/GSK3 $\beta$ pathway. Transl. Psychiatry 2015, 5, e528. [CrossRef]

40. Valencia, A.; Reeves, P.B.; Sapp, E.; Li, X.; Alexander, J.; Kegel, K.B.; Chase, K.; Aronin, N.; DiFiglia, M. Mutant huntingtin and glycogen synthase kinase 3-beta accumulate in neuronal lipid rafts of a presymptomatic knock-in mouse model of Huntington's disease. J. Neurosci. Res. 2010, 88, 179-190. [CrossRef]

41. Li, X.; Jope, R.S. Is glycogen synthase kinase-3 a central modulator in mood regulation? Neuropsychopharmacology 2010, 35, 2143-2154. [CrossRef] [PubMed]

42. Muneer, A. Wnt and GSK3 Signaling Pathways in Bipolar Disorder: Clinical and Therapeutic Implications. Clin. Psychopharmacol. Neurosci. 2017, 15, 100-114. [CrossRef] [PubMed]

43. Polter, A.; Beurel, E.; Yang, S.; Garner, R.; Song, L.; Miller, C.A.; Sweatt, J.D.; McMahon, L.; Bartolucci, A.A.; $\mathrm{Li}, \mathrm{X}$; et al. Deficiency in the inhibitory serine-phosphorylation of glycogen synthase kinase-3 increases sensitivity to mood disturbances. Neuropsychopharmacology 2010, 35, 1761-1774. [CrossRef] [PubMed]

44. Vogt, D.; Cho, K.K.A.; Lee, A.T.; Sohal, V.S.; Rubenstein, J.L.R. The parvalbumin/somatostatin ratio is increased in Pten mutant mice and by human PTEN ASD alleles. Cell Rep. 2015, 11, 944-956. [CrossRef]

45. Tilot, A.K.; Bebek, G.; Niazi, F.; Altemus, J.B.; Romigh, T.; Frazier, T.W.; Eng, C. Neural transcriptome of constitutional Pten dysfunction in mice and its relevance to human idiopathic autism spectrum disorder. Mol. Psychiatry 2016, 21, 118-125. [CrossRef] [PubMed]

46. Ou, M.L.; Liu, G.; Xiao, D.; Zhang, B.H.; Guo, C.C.; Ye, X.G.; Liu, Y.; Zhang, N.; Wang, M.; Han, Y.J.; et al. Association between miR-137 polymorphism and risk of schizophrenia: A meta-analysis. Genet. Mol. Res. 2016, 15, 3. [CrossRef] [PubMed]

47. Thomas, K.T.; Anderson, B.R.; Shah, N.; Zimmer, S.E.; Hawkins, D.; Valdez, A.N.; Gu, Q.; Bassell, G.J. Inhibition of the Schizophrenia-Associated MicroRNA miR-137 Disrupts Nrg1 $\alpha$ Neurodevelopmental Signal Transduction. Cell Rep. 2017, 20,1-12. [CrossRef]

48. Li, H.; Zhu, Z.; Liu, J.; Wang, J.; Qu, C. MicroRNA-137 regulates hypoxia-induced retinal ganglion cell apoptosis through Notch1. Int. J. Mol. Med. 2018, 41, 1774-1782. [CrossRef] 
49. Murphy, C.P.; Li, X.; Maurer, V.; Oberhauser, M.; Gstir, R.; Wearick-Silva, L.E.; Viola, T.W.; Schafferer, S.; Grassi-Oliveira, R.; Whittle, N.; et al. MicroRNA-Mediated Rescue of Fear Extinction Memory by miR-144-3p in Extinction-Impaired Mice. Biol. Psychiatry 2017, 81, 979-989. [CrossRef]

50. Camkurt, M.A.; Acar, Ş.; Coşkun, S.; Güneş, M.; Güneş, S.; Yılmaz, M.F.; Görür, A.; Tamer, L. Comparison of plasma MicroRNA levels in drug naive, first episode depressed patients and healthy controls. J. Psychiatr. Res. 2015, 69, 67-71. [CrossRef]

51. Olivieri, F.; Ahtiainen, M.; Lazzarini, R.; Pöllänen, E.; Capri, M.; Lorenzi, M.; Fulgenzi, G.; Albertini, M.C.; Salvioli, S.; Alen, M.J.; et al. Hormone replacement therapy enhances IGF-1 signaling in skeletal muscle by diminishing miR-182 and miR-223 expressions: A study on postmenopausal monozygotic twin pairs. Aging Cell 2014, 13, 850-861. [CrossRef] [PubMed]

52. Gururajan, A.; Naughton, M.E.; Scott, K.A.; O'Connor, R.M.; Moloney, G.; Clarke, G.; Dowling, J.; Walsh, A.; Ismail, F.; Shorten, G.; et al. MicroRNAs as biomarkers for major depression: A role for let-7b and let-7c. Transl. Psychiatry 2016, 6, e862. [CrossRef] [PubMed]

53. Sutton, L.P.; Rushlow, W.J. The effects of neuropsychiatric drugs on glycogen synthase kinase-3 signaling. Neuroscience 2011, 199, 116-124. [CrossRef] [PubMed]

54. Wan, S.; Xu, M.; Hu, L.; Yan, T.; He, B.; Xiao, F.; Bi, K.; Jia, Y. Schisandrin rescues depressive-like behaviors induced by chronic unpredictable mild stress via GDNF/ERK1/2/ROS and PI3K/AKT/NOX signaling pathways in mice. Psychiatry Res. 2017, 257, 230-237. [CrossRef] [PubMed]

55. Dudev, T.; Lim, C. Competition between $\mathrm{Li}+$ and $\mathrm{Mg} 2+$ in metalloproteins. Implications for lithium therapy. J. Am. Chem. Soc. 2011, 133, 9506-9515. [CrossRef] [PubMed]

56. Nohesara, S.; Ghadirivasfi, M.; Barati, M.; Ghasemzadeh, M.R.; Narimani, S.; Mousavi-Behbahani, Z.; Joghataei, M.; Soleimani, M.; Taban, M.; Mehrabi, S.; et al. Methamphetamine-induced psychosis is associated with DNA hypomethylation and increased expression of AKT1 and key dopaminergic genes. Am. J. Med. Genet. B Neuropsychiatr. Genet. 2016, 171, 1180-1189. [CrossRef]

57. He, Y.; Wang, P.; Wei, P.; Feng, H.; Ren, Y.; Yang, J.; Rao, Y.; Shi, J.; Tian, J. Effects of curcumin on synapses in APPswe/PS1dE9 mice. Int. J. Immunopathol. Pharmacol. 2016, 29, 217-225. [CrossRef]

58. Gao, Y.; Li, J.; Wu, L.; Zhou, C.; Wang, Q.; Li, X.; Zhou, M.; Wang, H. Tetrahydrocurcumin provides neuroprotection in rats after traumatic brain injury: Autophagy and the PI3K/AKT pathways as a potential mechanism. J. Surg. Res. 2016, 206, 67-76. [CrossRef]

59. Zhong, W.; Qian, K.; Xiong, J.; Ma, K.; Wang, A.; Zou, Y. Curcumin alleviates lipopolysaccharide induced sepsis and liver failure by suppression of oxidative stress-related inflammation via PI3K/AKT and NF- $\mathrm{KB}$ related signaling. Biomed. Pharmacother. 2016, 83, 302-313. [CrossRef]

60. Tao, W.; Dong, Y.; Su, Q.; Wang, H.; Chen, Y.; Xue, W.; Chen, C.; Xia, B.; Duan, J.; Chen, G. Liquiritigenin reverses depression-like behavior in unpredictable chronic mild stress-induced mice by regulating PI3K/Akt/mTOR mediated BDNF/TrkB pathway. Behav. Brain Res. 2016, 308, 177-186. [CrossRef]

61. Park, S.E.; Sapkota, K.; Kim, S.; Kim, H.; Kim, S.J. Kaempferol acts through mitogen-activated protein kinases and protein kinase B/AKT to elicit protection in a model of neuroinflammation in BV2 microglial cells. Br. J. Pharmacol. 2011, 164, 1008-1025. [PubMed]

62. Barry, R.L.; Byun, N.E.; Williams, J.M.; Siuta, M.A.; Tantawy, M.N.; Speed, N.K.; Saunders, C.; Galli, A.; Niswender, K.D.; Avison, M.J. Brief exposure to obesogenic diet disrupts brain dopamine networks. PLoS ONE 2018, 13, e0191299. [CrossRef] [PubMed]

63. Figlewicz, D.P.; Jay, J.; West, C.H.; Zavosh, A.; Hampe, C.S.; Radtke, J.R.; Raskind, M.A.; Peskind, E.R. Effect of dietary palmitic and stearic acids on sucrose motivation and hypothalamic and striatal cell signals in the rat. Am. J. Physiol. Regul. Integr. Comp. Physiol. 2018, 314, R191-R200. [CrossRef] [PubMed]

64. Mischoulon, D.; Freeman, M.P. Omega-3 fatty acids in psychiatry. Psychiatr. Clin. N. Am. 2013, 36, 15-23. [CrossRef] [PubMed]

65. Rapaport, M.H.; Nierenberg, A.A.; Schettler, P.J.; Kinkead, B.; Cardoos, A.; Walker, R.; Mischoulon, D. Inflammation as a predictive biomarker for response to omega-3 fatty acids in major depressive disorder: A proof-of-concept study. Mol. Psychiatry 2016, 21, 71-79. [CrossRef] [PubMed]

66. Bae, J.H.; Kim, G. Systematic review and meta-analysis of omega-3-fatty acids in elderly patients with depression. Nutr. Res. 2018, 50, 1-9. [CrossRef] 
67. Chia, S.C.; Henry, J.; Mok, Y.M.; Honer, W.G.; Sim, K. Fatty acid and vitamin interventions in adults with schizophrenia: A systematic review of the current evidence. J. Neural Transm. 2015, 122, 1721-1732. [CrossRef] [PubMed]

68. Lu, D.Y.; Tsao, Y.Y.; Leung, Y.M.; Su, K.P. Docosahexaenoic acid suppresses neuroinflammatory responses and induces heme oxygenase-1 expression in BV-2 microglia: Implications of antidepressant effects for $\omega-3$ fatty acids. Neuropsychopharmacology 2010, 35, 2238-2248. [CrossRef]

69. Li, J.; Jiang, K.; Zhao, F. Icariin regulates the proliferation and apoptosis of human ovarian cancer cells through microRNA-21 by targeting PTEN, RECK and Bcl-2. Oncol. Rep. 2015, 33, 2829-2836. [CrossRef]

70. Yang, J.; Zou, Y.; Jiang, D. Honokiol suppresses proliferation and induces apoptosis via regulation of the miR-21/PTEN/PI3K/AKT signaling pathway in human osteosarcoma cells. Int. J. Mol. Med. 2018, 41, 1845-1854. [CrossRef]

71. Aronchik, I.; Kundu, A.; Quirit, J.G.; Firestone, G.L. The antiproliferative response of indole-3-carbinol in human melanoma cells is triggered by an interaction with NEDD4-1 and disruption of wild-type PTEN degradation. Mol. Cancer Res. 2014, 12, 1621-1634. [CrossRef] [PubMed]

72. Motawi, T.M.; Hashem, R.M.; Rashed, L.A.; El-Razek, S.M. Comparative study between the effect of the peroxisome proliferator activated receptor-alpha ligands fenofibrate and n-3 polyunsaturated fatty acids on activation of 5'-AMP-activated protein kinase-alpha1 in high-fat fed rats. J. Pharm. Pharmacol. 2009, 61, 1339-1346. [CrossRef] [PubMed]

73. Armstrong, E.H.; Goswami, D.; Griffin, P.R.; Noy, N.; Ortlund, E.A. Structural basis for ligand regulation of the fatty acid-binding protein 5 , peroxisome proliferator-activated receptor $\beta / \delta($ FABP5-PPAR $\beta / \delta$ ) signaling pathway. J. Biol. Chem. 2014, 289, 14941-14954. [CrossRef]

74. Ghosh-Choudhury, T.; Mandal, C.C.; Woodruff, K.; St Clair, P.; Fernandes, G.; Choudhury, G.G.; Ghosh-Choudhury, N. Fish oil targets PTEN to regulate NFkappaB for downregulation of anti-apoptotic genes in breast tumor growth. Breast Cancer Res. Treat. 2009, 118, 213-228. [CrossRef] [PubMed]

(C) 2019 by the authors. Licensee MDPI, Basel, Switzerland. This article is an open access article distributed under the terms and conditions of the Creative Commons Attribution (CC BY) license (http:/ / creativecommons.org/licenses/by/4.0/). 